\title{
Ushikulides A and B, Immunosuppressants Produced by a Strain of Streptomyces sp.
}

\author{
Kosaku Takahashi, Teruhiko Yoshihara, Kazuhiko Kurosawa
}

Received: April 27, 2005 / Accepted: June 1, 2005

(C) Japan Antibiotics Research Association

Abstract Novel immunosuppressants, ushikulides A and $\mathrm{B}$, were isolated from the culture broth of Streptomyces sp. IUK-102. Ushikulides A and $B$ both have the same molecular formula, determined as $\mathrm{C}_{40} \mathrm{H}_{68} \mathrm{O}_{10}$. The structures of both compounds were elucidated to be novel 22-membered macrolides. Both compounds showed immunosuppressive activity for murine splenocyte proliferation in vitro.

Keywords 22-membered macrolides, ushikulide, immunosuppressants

Cyclosporin A [1] and FK506 [2], extremely potent immunosuppressive agents, have revolutionized organ transplantation by blocking the activation of lymphocytes and are widely used in preventing rejection. Cyclosporin A and FK506 respectively bind to cyclophilin and FK506binding protein (FKBP), so-called immunophilin [3]. Binding of each of these drug-protein complexes to a catalytic subunit of carcineurin causes inhibition of signal transduction in $\mathrm{T}$ cell activation [3]. However, these agents have some adverse side-effects such as nephrotoxicity and chronic rejection $[4,5]$. Another potent immunosuppressive agent is desired to develop a safer medical treatment. During our screening for immunosuppressants from microbial products, novel immunosuppressants ushikulides A (1) and B (2) were found in the culture broth of Streptomyces sp. IUK-102 (Fig. 1). This paper describes the isolation, structure elucidation, and biological activities of these compounds.

The producing strain, Streptomyces sp. IUK-102, was isolated from a soil sample collected in Ibaraki prefecture,<smiles>CCC(O)CC1COC2(CCC(C)C(CC(=O)C(C=CCCCC(C)(O)C(O)CC(O)C(C)C(O)C(C)C=CC(=O)OC3CC4(CCC(C)C(CC(C)C)O3)OC4C)CC)C2C)O1</smiles>

Compound 1<smiles>CCC(O)CC1OC2(CCC1C)CC(C)C(OC(=O)/C=C/C(C)C(O)C(C)C(O)CC(O)C(C)(O)CCCCC/C=C1\OC3CC(C)C(CC(C)C)OC3CC1=O)C2</smiles>

Compound 2

Fig. 1 Structures of ushikulides A (1) and B (2).

K. Takahashi (Corresponding author), T. Yoshihara: Graduate School of Agriculture, Hokkaido University, Sapporo, 060-8589, Japan, E-mail: kosaku@chem.agr.hokudai.ac.jp
K. Kurosawa: Department of Biology 68-370, Massachusetts Institute of Technology, 77 Massachusetts Avenue, Cambridge MA 02139, USA 
Japan. This strain was incubated at $27^{\circ} \mathrm{C}$ for five days in 500-ml Erlenmeyer flasks, each containing $70 \mathrm{ml}$ of medium composed of $\left(\mathrm{NH}_{4}\right)_{2} \mathrm{SO}_{4} 0.14 \%, \mathrm{KH}_{2} \mathrm{PO}_{4} 0.2 \%$, $\mathrm{CaCl}_{2} \quad 0.03 \%, \quad \mathrm{MgSO}_{4} \cdot 7 \mathrm{H}_{2} \mathrm{O} \quad 0.03 \%$, urea $0.03 \%$, polypepton $0.5 \%$, yeast extracts $0.1 \%$, soybean meal $3 \%$, glucose $1 \%$, soluble starch $0.5 \%, \mathrm{FeSO}_{4} \cdot 7 \mathrm{H}_{2} \mathrm{O} 0.005 \%$, $\mathrm{MnSO}_{4} \cdot 5 \mathrm{H}_{2} \mathrm{O} 0.0016 \%, \mathrm{ZnSO}_{4} \cdot 7 \mathrm{H}_{2} \mathrm{O} 0.0014 \%$, and $\mathrm{CoCl}_{2}$ $0.002 \%$ ( $\mathrm{pH} 7.0$ before sterilization). After fermentation on a rotary shaker $(230 \mathrm{rpm})$, four liters of the culture broth was centrifuged to separate mycelia and supernatant. The mycelia were extracted with acetone and the extract was evaporated to give an aqueous residue. This residue was then extracted with EtOAc and the soluble portion was concentrated in vacuo to obtain a brown residue $(3.5 \mathrm{~g})$. The residue was subjected to silica gel chromatography and eluted using $\mathrm{CHCl}_{3}$ followed by a mixture of $\mathrm{CHCl}_{3}$ and $\mathrm{MeOH}$ (90:10). Second elution with activity was evaporated and fractionated on a silica gel column using a mixture of $\mathrm{CHCl}_{3}$ and $\mathrm{MeOH}(95: 5)$. The fractions containing active substrates were combined and concentrated in vacuo. This active material was then subjected to reverse-phase HPLC (CAPCELL PAK $\mathrm{C}_{18}$ SG 120, Shiseido Co. Ltd., $20 \times 250 \mathrm{~mm}$ ) using a mixture of $\mathrm{CH}_{3} \mathrm{CN}$ and $\mathrm{H}_{2} \mathrm{O}(70: 30)$ as the isocratic mobile phase at a flow rate of $5.0 \mathrm{ml} /$ minute. Ushikulides A (1) and B (2) were eluted at 32.1 and 30.0 minutes, respectively. These fractions were collected and concentrated under reduced pressure. Finally, $\mathbf{1}(13 \mathrm{mg})$ and $\mathbf{2}(5 \mathrm{mg})$ were obtained as white powders.

Ushikulide A (1) was obtained as a colorless powder with a specific rotation of $-12.7^{\circ}\left(c 0.5, \mathrm{MeOH}, 25^{\circ} \mathrm{C}\right)$. The molecular formula of $\mathbf{1}$ was established as $\mathrm{C}_{40} \mathrm{H}_{68} \mathrm{O}_{10}$ on the basis of HRFAB-MS (found 709.4910, calcd. 709.4883 for $\mathrm{M}+\mathrm{H})$. The IR spectrum $(\mathrm{KBr})$ indicated the presence of hydroxyl and carbonyl groups at 3456 and $1719 \mathrm{~cm}^{-1}$, respectively. From ${ }^{1} \mathrm{H}$ and ${ }^{13} \mathrm{C}$ NMR spectral data, compound $\mathbf{1}$ was shown to possess a ketone, an ester carbonyl, $4 s p^{2}$ methines, $2 s p^{3}$ quaternary carbons, $13 s p^{3}$ methines including 7 oxymethines, $11 s p^{3}$ methylenes, and 8 methyl carbons. Seven degrees of unsaturation were inferred from the molecular formula. The COSY and TOCSY spectra of 1 indicated four ${ }^{1} \mathrm{H}-{ }^{1} \mathrm{H}$ spin coupling systems (Fig. 2). Spin systems A and B were connected through a series of HMBC correlations from H-34 to C-9, $\mathrm{C}-10$, and $\mathrm{C}-11$, and from $\mathrm{H}_{2}-11\left(\delta_{\mathrm{H}} 1.52 / 1.54\right)$ to $\mathrm{C}-10$. Spin systems B and $\mathrm{C}$ were linked by $\mathrm{HMBC}$ correlations of H-16 and H-18 $\left(\delta_{\mathrm{H}} 2.73\right)$ to $\mathrm{C}-17\left(\delta_{\mathrm{C}} 212.5\right)$. The long range couplings from $\mathrm{H}-2\left(\delta_{\mathrm{H}} 5.81\right)$ and $\mathrm{H}-21\left(\delta_{\mathrm{H}} 5.33\right)$ to $\mathrm{C}-1\left(\delta_{\mathrm{C}} 166.5\right)$ established the ester linkage of spin systems $\mathrm{A}$ and $\mathrm{C}$, indicating the presence of a 22 -membered lactone ring in the structure. The configurations of the two double

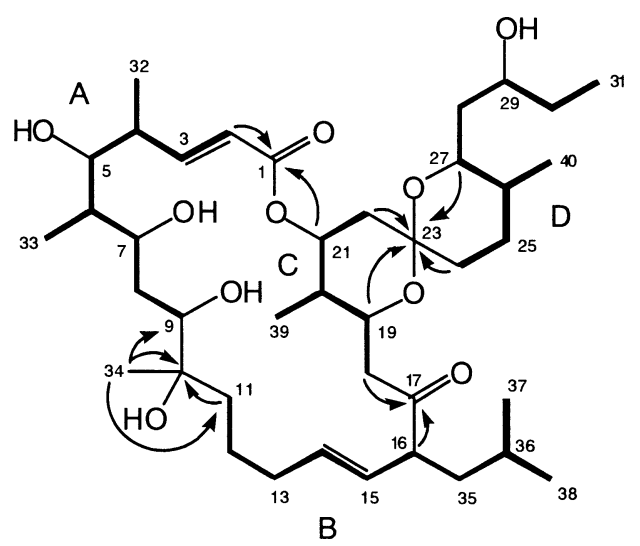

Fig. 2 2D-NMR correlations for 1. Bold lines show TOCSY correlations, and arrows show HMBC correlations.

bonds in the structure were demonstrated as $(E)$ by coupling constant values of $\mathrm{H}-2$ to $\mathrm{H}-3(15.7 \mathrm{~Hz})$, and $\mathrm{H}-14$ to $\mathrm{H}-15(15.0 \mathrm{~Hz})$. HMBC correlations from $\mathrm{H}-19, \mathrm{H}-22$, $\mathrm{H}-24$, and $\mathrm{H}-27$ to $\mathrm{C}-23\left(\delta_{\mathrm{C}} 98.9\right)$ indicated connectivity between spin systems $\mathrm{C}$ and $\mathrm{D}$ and the presence of $1,1^{\prime}$ dioxaspiro[5.5] undecane, which was fused onto the 22membered lactone structure. Accordingly, the structure of $\mathbf{1}$ was determined to be that shown in Fig. 1. All the assigned proton and carbon signals are listed in Table 1.

Ushikulide B (2) was obtained as a colorless powder with a specific rotation of $-46.7^{\circ}\left(c 0.5, \mathrm{MeOH}, 25^{\circ} \mathrm{C}\right)$. The molecular formula of $\mathbf{2}$ was determined to be $\mathrm{C}_{40} \mathrm{H}_{68} \mathrm{O}_{10}$ by HRFAB-MS (found 707.4728, calcd. 707.4734 for $\mathrm{M}-\mathrm{H}$ ), which was the same as that of $\mathbf{1}$. The IR spectrum $(\mathrm{KBr})$ indicated the presence of hydroxyl and carbonyl groups at 3437 and $1718 \mathrm{~cm}^{-1}$, respectively. Comparison of the ${ }^{1} \mathrm{H}$ NMR spectra of $\mathbf{2}$ and $\mathbf{1}$ revealed that the double bond proton signals at $\delta_{\mathrm{H}} 5.60$ and $\delta_{\mathrm{H}} 5.44$ present in $\mathbf{1}$ were missing in $\mathbf{2}$. Instead, a proton signal at $\delta_{\mathrm{H}} 6.97$ was identified in $2 .{ }^{13} \mathrm{C}$ NMR spectrum of $\mathbf{2}$ showed four carbon signals at $\delta_{\mathrm{C}} 152.2,149.4,143.5$, and 122.7 attributed to olefinic carbons. The significant difference observed between the NMR spectra resulted from a change in the olefin position. Besides this obvious difference, the 1D NMR spectra of these compounds resembled each other. Additionally, TOCSY and HMBC correlations of 2 (Fig. 3a) suggested that the basal structure of this compound was similar to that of $\mathbf{1}$, however, more information was still required to establish the structure of $\mathbf{2}$. Final structure confirmation was accomplished by a ROESY spectrum (Fig. 3b). The configuration of a double bond composed of C-15 and C-16 was shown to be $(E)$ from ROESY correlation between H-15 and H-18 $\left(\delta_{\mathrm{H}}\right.$ 2.31). Correlation of $\mathrm{H}-27$ with $\mathrm{H}-19$ revealed a spiroketal 
Table 1 NMR spectral data of ushikulides $A(\mathbf{1})$ and $B(\mathbf{2})$ in $\mathrm{CD}_{3} \mathrm{OD}$

\begin{tabular}{|c|c|c|c|c|}
\hline \multirow{2}{*}{ No. } & \multicolumn{2}{|l|}{ Ushikulide A (1) } & \multicolumn{2}{|l|}{ Ushikulide B (2) } \\
\hline & $\delta_{\mathrm{H}}(\mathrm{JHz})$ & $\delta_{\mathrm{C}}$ & $\delta_{\mathrm{H}}(\mathrm{JHz})$ & $\delta_{\mathrm{C}}$ \\
\hline 1 & & 166.5 & & 166.5 \\
\hline 2 & $5.81 d(15.7)$ & 122.7 & $5.80 \mathrm{~d}(15.8)$ & 122.7 \\
\hline 3 & $6.76 \mathrm{dd}(15.7,10.0)$ & 152.2 & $6.75 \mathrm{dd}(15.8,10.0)$ & 152.2 \\
\hline 4 & $2.46 \mathrm{~m}$ & 42.9 & $2.45 \mathrm{~m}$ & 43.0 \\
\hline 5 & 3.62 br.d (9.9) & 81.3 & 3.59 dd $(9.9,1.7)$ & 80.6 \\
\hline 6 & $1.56 \mathrm{~m}$ & 38.6 & $1.52 \mathrm{~m}$ & 39.7 \\
\hline 7 & 4.10 br.s & 76.0 & $4.03 \mathrm{~m}$ & 76.1 \\
\hline \multirow[t]{2}{*}{8} & $1.69 \mathrm{~m}$ & 36.4 & $1.52 \mathrm{~m}$ & 40.0 \\
\hline & $1.73 \mathrm{~m}$ & & $1.69 \mathrm{~m}$ & \\
\hline 9 & 3.17 br.d (10.8) & 75.0 & $3.28\left(\mathrm{CD}_{3} \mathrm{OD}\right.$ overlapped $)$ & 75.6 \\
\hline 10 & & 75.5 & & 75.4 \\
\hline \multirow[t]{2}{*}{11} & $1.52 \mathrm{~m}$ & 39.8 & $1.42 \mathrm{~m}$ & 39.9 \\
\hline & $1.54 \mathrm{~m}$ & & $1.57 \mathrm{~m}$ & \\
\hline \multirow[t]{2}{*}{12} & $1.43 \mathrm{~m}$ & 24.1 & $1.29 \mathrm{~m}$ & 23.6 \\
\hline & $1.52 \mathrm{~m}$ & & $1.47 \mathrm{~m}$ & \\
\hline \multirow[t]{2}{*}{13} & $2.04 \mathrm{~m}$ & 34.6 & $1.57 \mathrm{~m}$ & 30.4 \\
\hline & $2.23 \mathrm{~m}$ & & $1.63 \mathrm{~m}$ & \\
\hline \multirow[t]{2}{*}{14} & 5.60 ddd $(15.0,9.4,4.2)$ & 136.7 & $2.37 \mathrm{~m}$ & 29.8 \\
\hline & & & $2.44 \mathrm{~m}$ & \\
\hline 15 & $5.44 \mathrm{dd}(15.0,9.0)$ & 129.6 & $6.97 \mathrm{dd}(8.7,5.1)$ & 149.4 \\
\hline 16 & 3.07 ddd $(8.6,8.6,6.4)$ & 57.8 & & 143.5 \\
\hline 17 & & 212.5 & & 203.5 \\
\hline \multirow[t]{2}{*}{18} & $2.73 \mathrm{dd}(17.4,8.0)$ & 42.0 & $2.31 \mathrm{dd}(13.3,4.8)$ & 39.2 \\
\hline & $2.78 \mathrm{dd}(17.8,6.4)$ & & $3.60 \mathrm{dd}(13.3,10.9)$ & \\
\hline 19 & 4.33 br.t (6.3) & 67.2 & $4.19 \mathrm{~m}$ & 70.2 \\
\hline 20 & $2.05 \mathrm{~m}$ & 34.7 & $1.85 \mathrm{~m}$ & 34.7 \\
\hline 21 & 5.33 ddd $(11.1,5.4,5.4)$ & 71.3 & $5.21 \mathrm{ddd}(10.6,4.9,4.9)$ & 71.4 \\
\hline \multirow[t]{2}{*}{22} & $1.68 \mathrm{~m}$ & 36.4 & $1.72 \mathrm{~m}$ & 36.3 \\
\hline & $1.72 \mathrm{~m}$ & & & \\
\hline 23 & & 98.9 & & 99.4 \\
\hline \multirow[t]{2}{*}{24} & $1.43 \mathrm{~m}$ & 30.6 & $1.47 \mathrm{~m}$ & 30.5 \\
\hline & $1.65 \mathrm{~m}$ & & $1.67 \mathrm{~m}$ & \\
\hline \multirow[t]{2}{*}{25} & $1.40 \mathrm{~m}$ & 27.5 & $1.42 \mathrm{~m}$ & 27.6 \\
\hline & $2.19 \mathrm{~m}$ & & $2.14 \mathrm{~m}$ & \\
\hline 26 & $1.48 \mathrm{~m}$ & 32.1 & $1.59 \mathrm{~m}$ & 32.1 \\
\hline 27 & $4.02 \mathrm{~m}$ & 69.1 & $4.09 \mathrm{~m}$ & 69.3 \\
\hline \multirow[t]{2}{*}{28} & $1.28 \mathrm{~m}$ & 41.7 & $1.28 \mathrm{~m}$ & 41.4 \\
\hline & $1.63 \mathrm{~m}$ & & $1.62 \mathrm{~m}$ & \\
\hline 29 & 3.73 br.s & 70.6 & $3.78 \mathrm{~m}$ & 70.4 \\
\hline \multirow[t]{2}{*}{30} & $1.47 \mathrm{~m}$ & 31.9 & $1.49 \mathrm{~m}$ & 32.2 \\
\hline & $1.53 \mathrm{~m}$ & & $1.54 \mathrm{~m}$ & \\
\hline 31 & 0.97 t (7.4) & 10.2 & 1.00 t (7.4) & 10.3 \\
\hline 32 & $1.14 \mathrm{~d}(6.4)$ & 18.0 & $1.13 \mathrm{~d}(6.6)$ & 18.0 \\
\hline 33 & $0.85 d(6.9)$ & 4.2 & $0.85 d(6.9)$ & 4.9 \\
\hline 34 & $1.06 \mathrm{~s}$ & 22.7 & $1.08 \mathrm{~s}$ & 23.2 \\
\hline \multirow[t]{2}{*}{35} & $1.41 \mathrm{~m}$ & 41.3 & $2.22 \mathrm{~d}(7.1)$ & 35.3 \\
\hline & $1.53 \mathrm{~m}$ & & & \\
\hline 36 & $1.53 \mathrm{~m}$ & 26.7 & $1.63 \mathrm{~m}$ & 29.3 \\
\hline 37 & $0.91 d(5.9)$ & 23.2 & $0.86 d(5.4)$ & 23.0 \\
\hline 38 & 0.87 d (6.2) & 22.4 & $0.82 \mathrm{~d}(6.6)$ & 22.9 \\
\hline 39 & $0.79 d(6.9)$ & 6.2 & $0.92 \mathrm{~d}(6.9)$ & 6.1 \\
\hline 40 & $0.94 \mathrm{~d}(6.9)$ & 11.5 & $0.95 d(6.9)$ & 11.5 \\
\hline
\end{tabular}

${ }^{1} \mathrm{H}$ and ${ }^{13} \mathrm{C}$ NMR were observed at 500 and $125 \mathrm{MHz}$, respectively. 
(a)

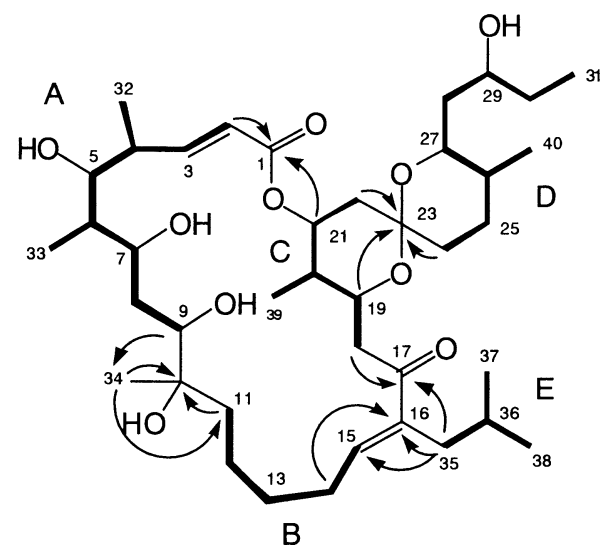

(b)

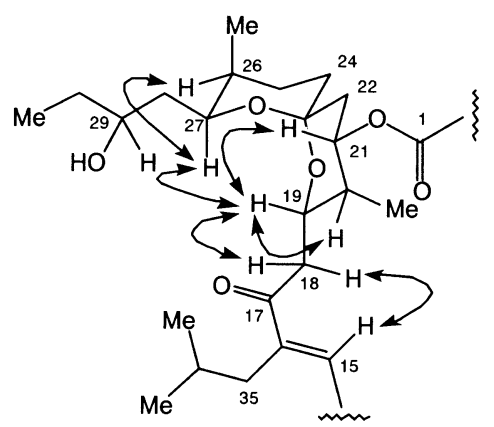

Fig. 3 2D-NMR correlations for 2: (a) TOCSY (bold lines) and HMBC (arrows) correlations, (b) key ROESY correlations for spiroketal moiety.

subunit connecting spin systems C and D. Moreover, additional ROESY cross peaks were observed as shown in Fig. $3 \mathrm{~b}$. The configuration of the spiroketal in $\mathbf{2}$ was quite similar to that in cytovaricin [6], therefore, the structure of 2 was determined as that in Fig. 1. The complete assignments of proton and carbon signals in $\mathbf{1}$ and $\mathbf{2}$ revealed the considerable difference of proton chemical shifts of $\mathrm{H}_{2}-18$ between these compounds (Table 1). This suggested that the positional change of the olefin near the ketone group caused a conformation of 22-membered lactone ring to be changed. As a result, $\mathrm{H}_{2}-18$ at $\delta_{\mathrm{H}} 2.31$ and 3.60 in 2 were placed in a shielding area of the ketone group and a deshielding area of the ketone group, respectively.

The immunosuppressive activities of these compounds were estimated by concanavalin A (ConA) stimulated lymphocyte blastogenesis [7]. Both compounds inhibited murine splenic lymphocyte proliferation with $\mathrm{IC}_{50}$ values of $70 \mathrm{nM}$, comparable to that of cyclosporin A. Compounds 1 and $\mathbf{2}$ did not show significant cytotoxicity for KB cells at a concentration of $10 \mu \mathrm{M}$.

Ushikulides A (1) and B (2) are related to phthoramycin [8], kaimonolide A [9], and the aglycone of cytovaricin [6, 10], which are thought to be members of the oligomycin family from the point of view of biosynthesis. Oligomycin F [11] and 41-demethylhomooligomycin B [12], which have a 26-membered lactone ring in their structures, are known to possess immunosuppressive activities. As far as we know, this is the first report describing a 22 -membered macrolide with a spiroketal moiety that shows immunosuppressive activity.

Acknowledgement We thank Dr. E. Fukushi and Mr. K.
Watanabe for measurements of mass spectral data.

\section{References}

1. Dreyfuss M, Harri E, Hoffmann H, Kobel H, Pache W, Tscherter H. Cyclosporin A and C. New metabolites from Trichoderma polysporum (Linx ex Pers.) Rifai. Eur J Appl Microbiol 3: 125-133 (1976)

2. Kino T, Hatanaka H, Hashimoto M, Nishiyama M, Goto T, Okuhara M, Kohsaka M, Aoki H, Imanaka H. FK-506, a novel immunosupressant isolated from a Streptomyces. I. Frementation, isolation, and physico-chemical and biological characteristics. J Antibiot 40: 1249-1255 (1987)

3. Schreiber SL, Crabtree GR. The mechanism of action of cyclosporin A and FK506. Immunology Today 13: 136-142 (1992)

4. The US Multicenter FK506 Liver Study Group. A comparison of tacrolimus (FK506) and cyclosporin for immunosuppression in liver transplantation. N Engl J Med 331: 1110-1115 (1994)

5. Atokinson P, Joubert G, Barron A, Grant D, Paradis K, Seidman E, Wall W, Rosenberg H, Howard J, Williams S, Stiller C. Hypertrophic cardiomyopahty associated with taclolimus in peadiatric transplant patients. Lancet 345: 894-896 (1995)

6. Evans DA, Skalder SW, Jones TK, Clardy J, Stout TJ. Total synthesis of the macrolide antibiotic cytovaricin. J Am Chem Soc 112: 7001-7031 (1990)

7. Kurosawa K, Takahashi K, Tsuda E. SNF4435C and D, novel immunosuppressants produced by a strain of Streptomyces spectabilis. I. Taxonomy, fermentation, isolation and biological activities. J Antibiot 54: 541-547 (2001)

8. Nakagawa A, Miura S, Imai H, Imamura N, Omura S. 
Structure and biosynthesis of a new antifungal antibiotic, phthoramycin. J Antibiot 42: 1324-1327 (1989)

9. Hirota A, Okada H, Kanza T, Nakayama M, Hirota H, Isogai A. Structure of kaimonolide A, a novel macrolide plant growth inhibitor from a Streptomyces strain. Agric Biol Chem 53: 2831-2833 (1989)

10. Kihara T, Kusakabe H, Nakamura G, Sakurai T, Isono K. Cytovaricin, a novel antibiotic. J Antibiot 34: 1073-1074 (1981)
11. Laatsch H, Kellner M, Wolf G, Lee YS, Hansske F, Konetschny-Rapp S, Pessara U, Scheuer W, Stockinger H. Oligomycin F, a new immunosuppressive homologue of oligomycin A. J Antibiot 46: 1334-1341 (1993)

12. Kim HS, Han SB, Kim HM, Kim YH, Lee JJ. 41Demethylhomooligomycin B, a new immunosuppresant antibiotic from Streptomyces ostreogriseus. J Antibiot 49: 1275-1277 (1996) 